\title{
Congenital Dermal Melanocytosis on the Foot: A Case Report and Review of the Literature
}

\author{
Soo Ick Cho ${ }^{1}$, Jungyoon Moon ${ }^{1}$, Gwanghyun $\mathrm{Jo}^{1}$, Cheol Lee ${ }^{2}$, Je-Ho Mun ${ }^{1,3}$ \\ Departments of ${ }^{1}$ Dermatology and ${ }^{2}$ Pathology, Seoul National University College of Medicine, ${ }^{3}$ Institute of Human-Environment Interface \\ Biology, Seoul National University, Seoul, Korea
}

Dermal melanocytosis is a common pigmented skin disease, characterized by an increased number of ectopic melanocytes in the dermis. Rare variants of dermal melanocytosis that do not belong to these four typical groups-nevus of Ota, nevus of Ito, blue nevus, and Mongolian spots-are called dermal melanocyte hamartoma, or congenital dermal melanocytosis (CDM) as it mostly appears from birth. We report a case of CDM on the foot of a young woman with a literature review of previously reported cases of CDM. (Ann Dermatol 31(2) $213 \sim 216,2019$ )

\section{-Keywords-}

Congenital, Dermis, Melanocytes, Nevus, blue, Pigmentation disorders

\section{INTRODUCTION}

Dermal melanocytosis is a common pigmented skin disease, characterized by an increased number of ectopic melanocytes in the dermis ${ }^{1}$. It is usually divided into four main groups: nevus of Ota, nevus of Ito, blue nevus, and Mongolian spots. Rare variants of dermal melanocytosis

Received November 3, 2017, Revised March 13, 2018, Accepted for publication March 21, 2018

Corresponding author: Je-Ho Mun, Department of Dermatology, Seoul National University Hospital, 101 Daehak-ro, Jongno-gu, Seoul 03080, Korea. Tel: 82-2-2072-1996, Fax: 82-2-742-7344, E-mail: jehomun@gmail.com ORCID: https://orcid.org/0000-0002-0734-2850

This is an Open Access article distributed under the terms of the Creative Commons Attribution Non-Commercial License (http://creativecommons. org/licenses/by-nc/4.0) which permits unrestricted non-commercial use, distribution, and reproduction in any medium, provided the original work is properly cited.

Copyright $\odot$ The Korean Dermatological Association and The Korean Society for Investigative Dermatology that do not belong to these four typical groups are called dermal melanocyte hamartoma, also referred as congenital dermal melanocytosis (CDM) because it mostly appears from birth ${ }^{2-5}$. Here, we report a case of CDM on the foot with a literature review of previously reported cases of CDM.

\section{CASE REPORT}

A 22-year-old woman presented with an asymptomatic, confluent, and pigmented skin lesion on the right foot dorsum since her birth. No specific changes occurred, including color and texture, except that the lesion enlarged in proportion to the growth of the body. She denied any significant medical problems and family history of pigmented disorders. On physical examination, mottled, confluent, and blue-gray macules and patches were observed on the right foot dorsum (Fig. 1A). We received the patient's consent form about publishing all photographic materials. Dermoscopic examination revealed a steel blue or gray structureless area surrounded by mottled brown globules (Fig. 1B). Skin biopsy demonstrated increased scattered melanocytes in the dermis without nest formation. Spindle and epithelioid melanocytes with melanin pigment were randomly oriented and dispersed among the collagen bundles. Immunohistochemical staining for Melan A showed positive staining for the melanocytes (Fig. 2). Based on the clinical and pathologic findings, the patient was diagnosed with CDM. She has been treated with three sessions of Q-switched $\mathrm{Nd}$ - YAG 1,064 mm laser without remarkable improvement.

\section{DISCUSSION}

Embryologically, melanocytes are derived from neural crest 


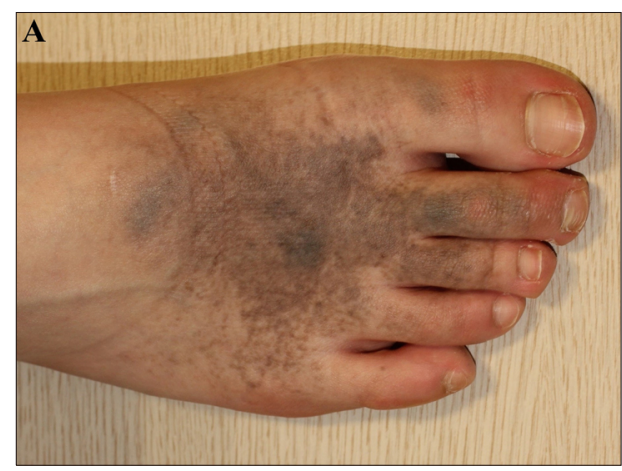

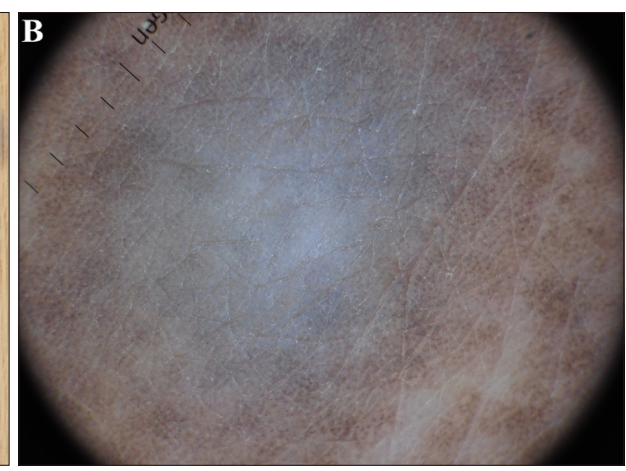

Fig. 1. (A) Mottled, confluent, bluegray macules surrounding darker patches on the right dorsum of the foot. (B) Steel blue or gray structureless area surrounded by mottled brown globules on dermoscopy.
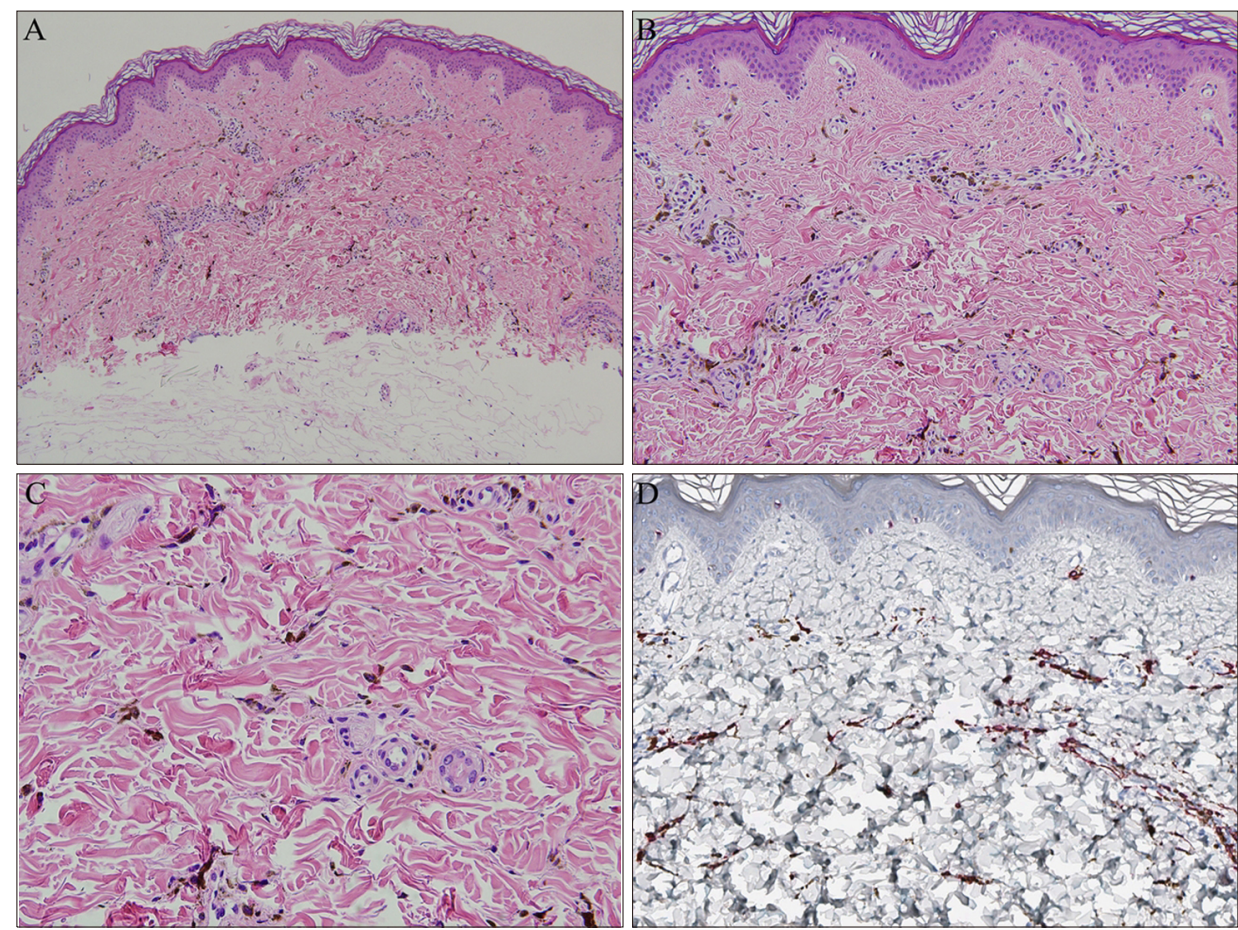

Fig. 2. $(A \sim C)$ Increased and scattered pigmented melanocytes without nest formation throughout the dermis. Scattered and elongated melanocytes among collagen bundles without certain orientation (H\&E; A: $\times 100, B: \times 200, C: \times 400$ ). (D) Melanocytes were positively stained for Melan-A (MART-1, ×200). cells originating from the ectoderm ${ }^{5}$. Dermal melanocytosis has been suggested to occur due to the arrest of melanocyte migration, resulting in increased number of melanocytes in the dermis ${ }^{5}$. Except for blue nevus, the other types of dermal melanocytosis share similar histopathologic findings and differ only in the concentration and location of melanocytes. The histopathologic finding shows elongated dermal melanocytes scattering between collagens ${ }^{1}$. Clinically, the types of dermal melanocytosis, such as nevus of Ota or Ito, are distinguished by their unique location-trigeminal or acromioclavicular distribution ${ }^{5}$. Dermal melanocyte hamartoma is a rare dermal melanocytosis pattern that does not fit into the typical classification of dermal melanocytosis ${ }^{2,5}$. In the present case, the pigmented lesion distribution differed from the nevus of Ota, nevus of Ito, and Mongolian spots. Additionally, the lesion was not matched to blue nevus, which shows a high concentration of dermal melanocytes in the dermis ${ }^{1}$. Several cases of CDM have been previously reported (Table 1$)^{1-4,6-10}$. Among the 10 cases including ours, 6 were reported at adults. Female predominance (male:female $=2: 8$ ) was observed similar to other dermal melanocytosis, such as the nevus of Ota. Segmental or dermatomal distribution was observed in five cases, localized pattern in four cases, and generalized form in one case. Among the cases with a localized pattern, the lesions were confined to the trunk or upper extremities ${ }^{3,9,10}$. CDM developing as an isolated patch on the foot similar to our case, has not been described. Clinically, CDM usually appears as uniform or mottled gray-blue patches with or without macules. Histopathologic findings revealed scattered melanocytes without nest formation throughout the dermis, 
Table 1. Clinical features of previously reported congenital dermal melanocytosis including the present case

\begin{tabular}{|c|c|c|c|c|c|c|}
\hline Case & Author & Age/sex & Distribution & Morphology & Histology & Prognosis \\
\hline 1 & $\begin{array}{l}\text { Bashiti } \\
\text { et al. }{ }^{6}\end{array}$ & $\begin{array}{c}4 \mathrm{~d} \\
/ \text { female }\end{array}$ & $\begin{array}{l}\text { Generalized distribution } \\
\text { (scalp, nose, ears, neck, } \\
\text { chest, abdomen, thighs, } \\
\text { legs, back and upper } \\
\text { extremities) }\end{array}$ & Blue-gray pigmentation & $\begin{array}{l}\text { Numerous melanocytes } \\
\text { in the dermis, more } \\
\text { numerous in the middle } \\
\text { and lower dermis }\end{array}$ & $\begin{array}{l}\text { Decreased } \\
\text { substantially at } \\
15 \text { months of age }\end{array}$ \\
\hline 2 & $\begin{array}{l}\text { Burkhart } \\
\text { and } \\
\text { Gohara }^{2}\end{array}$ & $\begin{array}{l}18 \mathrm{mo} \\
/ \mathrm{male}\end{array}$ & $\begin{array}{l}\text { Dermatomal distribution } \\
\text { (bilateral buttocks and } \\
\text { right leg) }\end{array}$ & $\begin{array}{l}\text { Gray-blue patch with } \\
\text { several conspicuous } \\
\text { macules }\end{array}$ & $\begin{array}{l}\text { Many melanocytes in } \\
\text { the upper two thirds of } \\
\text { the dermis }\end{array}$ & Persistent \\
\hline 3 & $\begin{array}{l}\text { Vélez } \\
\text { et al. }\end{array}$ & $\begin{array}{c}28 \mathrm{yr} \\
\text { /female }\end{array}$ & $\begin{array}{l}\text { Segmental distribution } \\
\text { (right aspect of the } \\
\text { trunk with several } \\
\text { thoracic dermatomes } \\
\text { affected) }\end{array}$ & $\begin{array}{l}\text { Mottled gray-blue } \\
\text { pigmentation with } \\
\text { numerous maculae } \\
\text { of darker hue }\end{array}$ & $\begin{array}{l}\text { Scattered melanocytes in } \\
\text { the dermis (two biopsy } \\
\text { specimens: numerous in } \\
\text { upper dermis or lower two } \\
\text { thirds of the reticular dermis) }\end{array}$ & Persistent \\
\hline 4 & $\begin{array}{l}\text { Grézard } \\
\text { et al. }\end{array}$ & $\begin{array}{c}45 \mathrm{yr} \\
\text { /female }\end{array}$ & $\begin{array}{l}\text { Dermatomal distribution } \\
\text { (two sides of the back } \\
\text { from the fourth to the ei- } \\
\text { ghth dorsal dermatomes) }\end{array}$ & Gray-blue pigmentation & $\begin{array}{l}\text { Scattered melanocytes } \\
\text { within the reticular dermis }\end{array}$ & Slowly spreading \\
\hline 5 & $\begin{array}{l}\text { Krishnan } \\
\text { et al. }{ }^{9}\end{array}$ & $\begin{array}{l}31 \mathrm{yr} \\
/ \mathrm{male}\end{array}$ & $\begin{array}{l}\text { Localized (lower left back } \\
\text { at the level of the } \mathrm{L} 1 \sim \mathrm{L} 2 \text { ) }\end{array}$ & $\begin{array}{l}\text { Speckled blue-brown } \\
\text { patch }\end{array}$ & Not reported & Persistent \\
\hline 6 & $\begin{array}{l}\text { Kim } \\
\text { et al. }{ }^{10}\end{array}$ & $\begin{array}{c}21 \mathrm{yr} \\
/ \text { female }\end{array}$ & Localized (right arm) & $\begin{array}{l}\text { Relatively well-demarc- } \\
\text { ated bluish round patch } \\
\text { encircled by larger } \\
\text { brownish patch }\end{array}$ & $\begin{array}{l}\text { Scattered melanocytes in the } \\
\text { dermis of the central bluish } \\
\text { patch and increased basal } \\
\text { pigmentation in the epider- } \\
\text { mis of the surrounding } \\
\text { brownish patch }\end{array}$ & $\begin{array}{l}\text { Persistent } \\
\text { (removed by } \\
\text { surgical excision } \\
\text { and 532-nm } \\
\text { Q-switched } \\
\text { Nd-YAG) }\end{array}$ \\
\hline 7 & $\begin{array}{l}\text { Kim } \\
\text { et } \text { al. }^{3}\end{array}$ & $\begin{array}{c}5 \mathrm{yr} \\
\text { /female }\end{array}$ & Localized (left palm) & Speckled bluish patch & $\begin{array}{l}\text { Scattered melanocytes } \\
\text { in the dermis }\end{array}$ & Persistent \\
\hline 8 & $\begin{array}{l}\text { Lee } \\
\text { et al. }{ }^{1}\end{array}$ & $\begin{array}{l}21 \text { mo } \\
\text { /female }\end{array}$ & $\begin{array}{l}\text { Segmental distribution } \\
\text { (left unilateral aspect } \\
\text { of face, neck, chest, } \\
\text { shoulder and back) }\end{array}$ & $\begin{array}{l}\text { Uniform deep blue } \\
\text { patches with a few dark } \\
\text { blue-brown macules }\end{array}$ & $\begin{array}{l}\text { Scattered melanocytes } \\
\text { in the dermis, numerous } \\
\text { in the upper and middle } \\
\text { dermis }\end{array}$ & $\begin{array}{l}\text { Persistent at } 21 \\
\text { months of age }\end{array}$ \\
\hline 9 & $\begin{array}{l}\text { Pessach } \\
\text { et al. }{ }^{4}\end{array}$ & $\begin{array}{c}4 \text { mo } \\
\text { /female }\end{array}$ & $\begin{array}{l}\text { Dermatomal distribution } \\
\text { (trunk and upper } \\
\text { extremities) }\end{array}$ & $\begin{array}{l}\text { Uniform gray-blue } \\
\text { patches with several } \\
\text { darker blue macules }\end{array}$ & $\begin{array}{l}\text { Numerous melanocytes } \\
\text { in the upper dermis }\end{array}$ & $\begin{array}{l}\text { Persistent at } 4 \\
\text { months of age }\end{array}$ \\
\hline 10 & $\begin{array}{l}\text { Present } \\
\text { case }\end{array}$ & $\begin{array}{c}22 \mathrm{yr} \\
\text { /female }\end{array}$ & $\begin{array}{l}\text { Localized (right dorsum } \\
\text { of the foot) }\end{array}$ & $\begin{array}{l}\text { Mottled and pigmented } \\
\text { brownish macules sur- } \\
\text { rounding darker patches }\end{array}$ & $\begin{array}{l}\text { Scattered melanocytes in } \\
\text { the dermis }\end{array}$ & Persistent \\
\hline
\end{tabular}

which were subtly different from the nevus of Ota or Ito (melanocytes detected mainly in the upper dermis), and Mongolian spot (mostly in the lower dermis) ${ }^{1}$. In most cases, the pigmentation did not disappear with age. However, in one case, a 4-day-old neonate had shown generalized blue-gray pigmentation that gradually faded until 15 months of age. Although the case was reported as a generalized dermal melanocytosis, we speculate that the case might be difficult to be differentiated from extrasacral Mongolian spot because it tends to disappear or fade during childhood ${ }^{7}$.

In conclusion, we report a rare case of CDM on the foot with relevant literature review. Further studies are necessary to elucidate the clinical and pathogenetic character- istics of CDM.

\section{CONFLICTS OF INTEREST}

The authors have nothing to disclose.

\section{ORCID}

Soo Ick Cho, https://orcid.org/0000-0003-3414-9869

Jungyoon Moon, https://orcid.org/0000-0002-7575-0063

Gwanghyun Jo, https://orcid.org/0000-0003-0580-2312

Cheol Lee, https://orcid.org/0000-0001-5098-8529

Je-Ho Mun, https://orcid.org/0000-0002-0734-2850 


\section{REFERENCES}

1. Lee S, Kim DH, Lee G, Whang KU, Lee JS, Park YL. An unusual case of congenital dermal melanocytosis. Ann Dermatol 2010;22:460-462.

2. Burkhart CG, Gohara A. Dermal melanocyte hamartoma. A distinctive new form of dermal melanocytosis. Arch Dermatol 1981;117:102-104.

3. Kim S, Kim JA, Kim WS, Lee JH, Yang JM. Congenital dermal melanocytosis confined to the palm. J Eur Acad Dermatol Venereol 2007;21:1116-1117.

4. Pessach Y, Goldberg I, Sprecher E, Gat A, Harel A. An unusual presentation of congenital dermal melanocytosis fitting the rare diagnosis of dermal melanocyte hamartoma. Cutis 2014;94:E16-E17.

5. Franceschini D, Dinulos JG. Dermal melanocytosis and associated disorders. Curr Opin Pediatr 2015;27:480-485.
6. Bashiti HM, Blair JD, Triska RA, Keller L. Generalized dermal melanocytosis. Arch Dermatol 1981;117:791-793.

7. Vélez A, Fuente C, Belinchón I, Martín N, Furió V, Sánchez Yus E. Congenital segmental dermal melanocytosis in an adult. Arch Dermatol 1992;128:521-525.

8. Grézard P, Berard F, Balme B, Perrot H. Congenital bilateral dermal melanocytosis with a dermatomal pattern. Dermatology 1999;198:105-106.

9. Krishnan RS, Roark TR, Hsu S. Isolated patch of speckled, congenital, pigmented dermal melanocytosis outside the face or acromioclavicular regions. J Eur Acad Dermatol Venereol 2003;17:238-239.

10. Kim S, Park JH, Kim JA, Lee JH, Yang JM, Lee ES, et al. Congenital combined dermal and epidermal melanocytosis: a new entity? J Eur Acad Dermatol Venereol 2007;21:12821283. 